DOI https://doi.org/10.30525/978-9934-588-81-5-2.9

\title{
ВИКЛАДАННЯ МЕДИЧНОЇ ПСИХОЛОГІЇ З ПОЗИЦІЙ ПСИХОДИНАМІЧНОГО ПІДХОДУ
}

\author{
Кахно I. B. \\ кандидат психологічних наук, \\ доцент кафедри психіатрї, наркології та медичної психологї \\ Івано-Франківський національний медичний університет \\ Краснопольська I. I. \\ асистент кафедри психіатрії, наркологї та медичної психології \\ Івано-Франківський національний медичний університет \\ м. Івано-Франківськ, Украӥна
}

Підходячи до викладання медичної психології з психодинамічних позицій, ми мали на меті прокласти місток між вивченням теоретичних базових дисциплін (загальна психологія) і суто клінічних (психіатрія). Оскільки психодинамічний підхід вже давно посів належне місце в загальній психології і $є$ безумовно важливою складовою в існуючій біопсихосоціальній моделі сучасної психіатрії, нам здалося доцільним розглядати основні питання медичної психології власне 3 психодинамічної перспективи, використовуючи психоаналіз не лише як метод психотерапії, але і як спосіб розуміння психічного життя, формування особистості та особливостей психологічного реагування на різноманітні зовнішні і внутрішні чинники, зокрема на хворобу.

Медична психологія викладається студентам медичного університету на третьому році навчання, коли вони вже отримали достатню теоретичну базу і $є$ дотичні до клінічних дисциплін, маючи можливість на практиці оцінювати вплив загальної хвороби на психологічний стан пацієнта, типи реагування на хворобу, особливості комунікації в лікувальному середовищі тощо.

Теми висвітлюються в лекційному матеріалі і розроблених нами навчальних посібниках, отримані знання закріплюються на відповідних практичних заняттях, де студенти набувають практичних навичок та вмінь.

Тема «Психодинамічні теорії особистості» ставить за мету ознайомити студентів з основними поняттями психоаналітичного підходу в психології. Вивчаються найважливіші теорії особистості, які мають найбільше теоретичне і клінічне значення, студенти опановують основні теорії розвитку особистості - теорію психосексуального розвит- 
ку 3.Фрейда та теорію психосоціального розвитку Е. Еріксона. В подальшому викладається тема «Механізми психологічного захисту». В процесі онтогенетичного розвитку у кожної людини формується певна сукупність механізмів психологічного захисту (які і являють собою інтрапсихічну адаптацію), що визначає тип і рівень особистісної організації. Вказані механізми, первинним завданням яких є ефективна адаптація та збереження біологічного, інтрапсихічного і поведінкового гомеостазу, при певних умовах призводять до дезадаптації та приймають вирішальну участь у процесах симптомоутворення. При вивченні психологічних захистів використовуються ситуаційні завдання, ілюстративні матеріали в формі психологічних віньєток, витягів 3 літературних творів та художніх фільмів. Використовуються також експериментально-психологічні методики (опитувальник для діагностики психологічних захистів Плутчека-Келермана-Конте - Life Style Index) [6, c. 5-152]. На занятті з теми «Рівні організації особистості», котра $є$ логічним продовженням попередніх тем і однією 3 найскладніших для опанування, студенти вивчають психодинамічну «діагностичну систему координат» [7, с. 61-93], яка має два виміри. Перший вимір - це рівень особистісної організації, який характеризує рівень розвитку особистості, іiі адаптивні можливості, і загалом, ступінь психологічного благополуччя або неблагополуччя індивіда (психотичний, межовий та невротичний рівні організації особистості). Другий вимір - тип особистісної організації - це певний патерн імпульсів, тривог, захисних механізмів, який надає людині унікальності і в певних ситуаціях, які перевищують адаптивні можливості індивіда, може зумовити декомпенсацію у вигляді відповідного розладу. На практичних заняттях з означених тем студенти також опановують основні навички 3 проведення діагностичного структурованого інтерв'ю, яке дає змогу визначитись 3 провідними захисними механізмами та особистісним радикалом пацієнта, визначити тип реагування на хворобу та проаналізувати кореляції певних типів особистісної організації з типами реагування на хворобу [3, с. 9-25]. Застосовуються елементи ділової гри для визначення оптимального способу комунікації з пацієнтами з різними типами особистості (нарцистичний, параноїчний, обсесивно-компульсивний тощо).

Питання усвідомлення хвороби і ставлення до неї хворого розглядаються з позицій типів особистісної організації, переважаючих механізмів психологічного захисту. До уваги береться важкість і „соціальна обтяженість» захворювання, а також актуальна життєва ситуація хворого. На відповідних практичних заняттях в ситуаційних завданнях студенти розглядають розгорнуті описи клінічних випадків реагу- 
вання на хворобу і формування внутрішньої картини хвороби у пацієнтів з різними типами особистості. 3 позиції механізмів психологічного захисту розглядаються етапи психологічної реакції особистості на невиліковну смертельну хворобу, типи реагування родичів хворого, способи найбільш адекватної поведінки лікаря при різних типах реагування хворого і його родичів на хворобу.

Елементи психодинамічного підходу широко використовуються при вивченні психосоматичних взаємовпливів. Психодинамічні механізми внутрішніх конфліктів з фіксацією на певних стадіях психосексуального розвитку та формуванням відповідних наборів психологічних захистів багато в чому корелюють 3 поглядами Ф. Александера [1, с. 29-73] щодо не розрішених внутрішніх конфліктів, Ф. Данбар [2, с. 151] стосовно впливу не лише тривалих емоційних переживань на тілесність, а й наявності ряду так званих психосоматичних особистісних профілів та концепцією алекситимії [2, с. 159].

При вивченні стосунків хворого з лікарем акцент робиться на психологічних механізмах перенесення і контрперенесення. Ці механізми $\epsilon$ актуальними не лише в стосунках психоаналітичного сеттінгу [5, с. 59-143], але в будь-яких стосунках лікар-пацієнт та й навіть в міжособових стосунках в більш широкому значенні. Детально розглядаються механізми перенесення у пацієнтів з різними типами особистості і рівнями особистісної організації, а також види контреперенесення та типові реакції лікаря залежно від типів особистості хворого і самого лікаря. Теоретичний матеріал ілюструється конкретними прикладами взаємостосунків лікаря і хворого, висвітлюються способи оптимізації цих взаємостосунків. Розглядаються також питання конфліктних ситуацій в лікувально-діагностичному процесі. На практичному занятті з елементами ділової гри моделюються найбільш типові конфліктні ситуації, обговорюються способи їх попередження і подолання. Підкреслюється значення групового обговорення, зокрема функціонування балінтовських груп в медичному колективі та їх значення в розрішенні і попередженні конфліктів [4, с. 5-89]. Робота таких груп в медичному колективі за участі модератора-психолога дозволяє зняти надмірну психологічну напруженість, вирішити психологічно складні професійні ситуації шляхом обговорення в групі.

В питаннях, що стосуються особистості лікаря, медичної етики та деонтології, висвітлюються психодинамічні аспекти особистості лікаря, зв'язок типу особистості лікаря 3 його професійним стилем та копінговими стратегіями, адаптивні та неадаптивні способи подолання внутрішніх і зовнішніх конфліктів. Особлива увага надається актуальній темі емоційного та професійного вигорання, встановленню 
ранніх ознак вигорання [8, с. 34-49]. Розглядаються різні методи боротьби із стресом, встановлюються найбільш адаптивні для майбутньої професії способи подолання емоційного напруження з урахуванням типу особистості.

Як результат викладання медичної психології з позицій психодинамічного підходу ми відмітили більшу замотивованість студентів до вивчення психологічних дисциплін, більшу здатність відрефлектовувати власні переживання та 3 розумінням ставитись до переживань пацієнтів. На сучасному етапі розвитку медицини, коли лікарюпочатківцю доводиться щоденно навчатись, опановуючи великі масиви фахової інформації, дуже важливим є набути професійних медикопсихологічних знань ще в процесі університетської підготовки, опанувати важливі навички професійного спілкування та набути вміння знайти психологічний підхід до пацієнта, дотримуватись деонтологічних норм, створювати прийнятний психологічний робочий клімат у колективі, запобігаючи конфліктам або сприяючи конструктивному їх вирішенню, вміти розпізнавати ранні ознаки емоційного вигорання та долати їх адаптивними способами.

\section{Література:}

1. Александер Ф. (2002). Психосоматическая медицина. Принципы и практическое применение. Пер. с англ. М.: ЭКСМО - Пресс. - 363 с.

2. Былкина Н.Д. (1997) Развитие зарубежных психосоматических теорий (аналитический обзор). Психологический журнал. Т. 18. № 2. C. $149-160$.

3. Вассерман Л.И., Иовлев Б.В., Карпова Э.Б., Вукс А.Я. (2009). Психологическая диагностика отношения к болезни: пособие для врачей. СПб. : НИПНИ им. В.М. Бехтерева.

4. Винокур В. А. (2015). Балинтовские группы: история, технология, структура, границы и ресурсы : учебное пособие. СПб : СпецЛит. - 191 с.

5. Грин А. (2007). Терапевтические отношения в психоанализе. М. : Когито-Центр. - 236 с.

6. Кружков, О.В., Шахматова О.Н. (2006). Психологические защиты личности: учебное пособие. Екатеринбург: Издательство Росгоспрофпедуниверситет. 153 стр.

7. Мак-Вильямс Н. (2015). Психоаналитическая диагностика: Понимание структуры личности в клиническом процессе. Psychoanalytic Diagnosis. Understanding Personaly Structure in the Clinical Process. НФ Класс, 592 с. 